\title{
Bioelektryczna aktywność spoczynkowa mózgu osób z obustronnymi szumami usznymi - wyniki wstępne
}

\section{Resting state bioelectrical activity in patients with chronic bilateral tinnitus - preliminary results}

\author{
Monika Lewandowska ${ }^{1}$, Rafał Milner², Małgorzata Ganc ${ }^{2}$, Iwona Niedziałek³ \\ Lucyna Karpiesz ${ }^{3}$, Tomasz Wolak ${ }^{1}$, Henryk Skarżyński ${ }^{4}$ \\ ${ }^{1}$ Instytut Fizjologii i Patologii Słuchu, Światowe Centrum Słuchu, Naukowe Centrum Obrazowania \\ Biomedycznego, Kajetany \\ ${ }^{2}$ Instytut Fizjologii i Patologii Słuchu, Światowe Centrum Słuchu, Zakład Audiologii Eksperymentalnej, Kajetany \\ ${ }^{3}$ Instytut Fizjologii i Patologii Słuchu, Klinika Audiologii i Foniatrii, Kajetany \\ ${ }^{4}$ Instytut Fizjologii i Patologii Słuchu, Światowe Centrum Słuchu, Kajetany
}

Adres autora: Monika Lewandowska, Światowe Centrum Słuchu, Naukowe Centrum Obrazowania Biomedycznego, ul. Mokra 17, Kajetany, 05-830 Nadarzyn, e-mail: m.lewandowska@ifps.org.pl

\section{Streszczenie}

Cel: Celem pracy jest określenie wzorców spoczynkowej bioelektrycznej aktywności mózgu u pacjentów z przewlekłymi obustronnymi szumami usznymi.

Materiał i metody: U 6 pacjentów z szumami usznymi i 7 osób bez szumów usznych, dopasowanych do grupy klinicznej pod względem płci i wieku, zarejestrowano spoczynkową aktywność bioelektryczną mózgu w stanie relaksacji z oczami otwartymi oraz z oczami zamkniętymi. Uzyskany sygnał EEG poddano analizie ilościowej (ang. quantitative EEG, QEEG).

Wyniki: Wykazano specyficzny wzorzec spoczynkowej czynności elektrofizjologicznej mózgu u osób z szumami usznymi przejawiający się wzmożoną ekspresją fal wolnych (delta, theta i alfa) w obszarach czołowo-skroniowych, skroniowych i potylicznych oraz fal szybkich $(12-25 \mathrm{~Hz})$ w prawej okolicy skroniowej.

Wnioski: Wstępne wyniki badań aktywności spoczynkowej mózgu u pacjentów odczuwających szumy uszne wskazują na zaangażowanie wielu struktur, również tych nienależących do ośrodkowego układu słuchowego, w proces percepcji tinnitusa. Badania mogą przyczynić się do rozwoju istniejących metod diagnostyki i terapii szumów usznych.

Słowa kluczowe: szumy uszne • aktywność spoczynkowa mózgu • ilościowe EEG

Abstract

Aim of the study: The goal of this study was to identify patterns of resting state bioelectrical activity in patients suffering from chronic, bilateral tinnitus.

Material and methods: The resting state EEG activity was registered in 6 tinnitus patients and 7 gender and age-matched control subjects during relaxation with open or closed eyes. EEG signal was analyzed using method of quantitative EEG (QEEG).

Results: A specific pattern of the resting state EEG activity in tinnitus subjects was found. It was characterized by increased slow activity (delta, theta and alpha) in the fronto-temporal, temporal and occipital areas of the brain as well as increased beta waves $(12-25 \mathrm{~Hz})$ in the right auditory cortex.

Conclusions: Preliminary results of the study indicate the involvement of many auditory and non-auditory brain structures in the process of tinnitus generation. This study may have important implications for the diagnosis and therapy of tinnitus patients.

Key words: tinnitus • resting EEG activity • quantitative EEG (QEEG) 


\section{Wstęp}

Subiektywne szumy uszne (ang. tinnitus, łac. tinnire, „dzwonić”, „dzwonienie”) to wrażenia słuchowe słyszane wyłącznie przez osobę, u której powodują dyskomfort $[1,2]$. Subiektywne szumy uszne stanowią zjawisko fantomowe, powstają bez pobudzenia ślimaka i wynikają wyłącznie z aktywności układu nerwowego. Nie można ich obiektywnie ocenić ani zarejestrować. Tinnitus może przybierać różne formy: szumu, pisku, syku uciekającego powietrza, dzwonienia, cykania świerszczy, pukania [2]. Może być słyszany w jednym uchu, obojgu uszach lub pochodzić ze środka głowy.

Szacuje się, że w Polsce co dziesiąta osoba między 55 a 64 rż. i co piąta po 75 rż. cierpi na szumy uszne [3]. Istotnym czynnikiem zwiększającym ryzyko pojawienia się tinnitusa jest narażenie na hałas, zwłaszcza przemysłowy, oraz słuchanie głośnej muzyki. Szumom usznym często towarzyszą zaburzenia słuchu, nadwrażliwość słuchowa, a także zaburzenia koncentracji oraz problemy emocjonalne, takie jak: wzmożone napięcie, depresja.

Mózgowy mechanizm powstawania subiektywnych szumów usznych nie został do końca poznany. Większość autorów jest zgodna w kwestii, że przyczyną szumów usznych są patologiczne zmiany zachodzące w obrębie obwodowego i/lub ośrodkowego układu słuchowego [4-6]. Najnowsze badania $\mathrm{z}$ zastosowaniem metod neuroobrazowania (PET, fMRI) z udziałem ludzi wykazały, że obecność szumu usznego wiąże się z nieprawidłową aktywnością struktur wyższych pięter drogi słuchowej: śródmózgowia (wzgórków czworaczych dolnych) [7-10], ciała kolankowatego bocznego oraz projekcyjnej i asocjacyjnej kory słuchowej $[11,12]$. Istnieją również dowody na reorganizację mapy tonotopowej pierwotnej kory słuchowej u pacjentów z szumami usznymi [13-15].

Obecnie przeważają poglądy, że zmiany w obrębie ośrodkowego układu słuchowego mogą być konieczne, ale niewystarczające do powstania wrażenia szumów usznych. Jeśli bowiem prawdziwa jest koncepcja, że uszkodzenie niższych pięter układu słuchowego skutkuje reorganizacją centralnego układu słuchowego, dlaczego tylko niektórzy pacjenci z uszkodzeniem słuchu spowodowanym urazem akustycznym mają szumy uszne. Ponadto okazuje się, że brzmienie i intensywność szumu można modulować za pomocą czynników niezwiązanych z modalnością słuchową, tj. ruchów żuchwy, oczu czy karku [16]. Nie należy również zapominać, że stres czy deprywacja snu mogą nasilać wrażenie szumów usznych [17]. Wreszcie nierzadko zdarza się, że szumy uszne są słyszane przez pewien czas, potem samoistnie znikają, żeby znowu się pojawić po upływie kilku dni, a nawet tygodni. Obserwacje te sugerują istnienie obszarów w mózgu nienależących do ośrodkowego układu słuchowego, które pełniłyby rolę swoistego „włącznika” i „wyłącznika” szumów w uszach.

Debata na temat roli struktur mózgu nienależących do układu słuchowego w powstawaniu wrażenia szumów usznych toczy się od czasu, kiedy P. Jastreboff zaproponował neurofizjologiczny model generacji tinnitusa [4], zgodnie z którym u osób nieodczuwających silnego dyskomfortu związanego z percepcją szumów usznych zmiany w pracy mózgu zachodzą wyłącznie w obrębie układu słuchowego. Z kolei u pacjentów odczuwających silne negatywne emocje związane ze słyszeniem szumów usznych stwierdza się nieprawidłową pracę autonomicznego układu nerwowego (AUN) oraz nadaktywność struktur układu limbicznego. Zgodnie z teorią Jastreboffa, to utrzymujące się przez dłuższy czas pobudzenie AUN i systemu limbicznego, pochodzące z kory lub niższych pięter układu słuchowego, jest odpowiedzialne za słyszenie szumów w uszach.

Najnowsze badania $\mathrm{z}$ zastosowaniem technik neuroobrazowania u pacjentów z przewlekłymi szumami usznymi dostarczają wyników tylko częściowo potwierdzających tę teorię. Wykazano w nich nadmierną aktywność następujących struktur układu limbicznego: ciała migdałowatego [18], przedniego i tylnego zakrętu obręczy $[18,19]$, hipokampa $[10,20]$ oraz obszaru pod spoidłem wielkim obejmującego jądro półleżące $[21,22]$. Aktywację układu limbicznego obserwowano jednak zarówno u osób, u których szumy uszne wywoływały negatywne emocje, jak i u osób, które przyzwyczaiły się do ich obecności. Skłoniło to niektórych badaczy [6] do zrewidowania modelu generacji szumów usznych. Autorzy nowej koncepcji, która aktualnie poddawana jest empirycznej weryfikacji $[6,22]$, proponują istnienie mózgowego "mechanizmu wyciszania szumu usznego" (ang. noise-cancellation mechanism), który w przypadku pacjentów z szumami usznymi nie działa w sposób efektywny. Za proces hamowania tinnitusa odpowiedzialne są struktury należące do układu limbicznego: jądro półleżące (nucleus accumbens) i jądro siatkowate wzgórza. Współdziałanie tych struktur mózgu prowadzi do zahamowania aktywności neuronalnej odpowiedzialnej za powstanie szumów, w efekcie czego nie dociera ona do kory i szum uszny nie jest percypowany.

Uszkodzenie obwodowego układu słuchowego generuje wzmożoną aktywność neuronalną, która inicjuje proces percepcji szumu usznego. Prawidłowo działający mechanizm wyciszania szumów usznych powoduje, że ta nadaktywność w obrębie układu słuchowego jest wykrywana przez układ limbiczny i eliminowana przez jądro siatkowate, które hamuje aktywność innego jądra wzgórza, odpowiadającego za słyszenie nieprzyjemnych dźwięków (ciało kolankowate boczne). To zjawisko inhibicyjne powtarzane przez dłuższy czas (np. podczas terapii) prowadzi do odfiltrowania specyficznej, niechcianej stymulacji, która w konsekwencji nie dociera do kory słuchowej. Tym samym wrażenie szumu usznego nie powstaje. Tak długo jak system jądra półleżącego pozostaje nienaruszony, sygnał szumu usznego jest odfiltrowany i nie zostaje przekazany do kory słuchowej. Natomiast jeśli system jądra półleżącego przestanie realizować swoją funkcję, eliminacja szumu na poziomie wzgórza nie jest możliwa i w korze mózgu powstaje wrażenie szumu usznego. Następuje trwała reorganizacja kory słuchowej, której konsekwencją jest przewlekły szum w uszach. Zgodnie z teorią Rauscheckera bezsenność, często współwystępująca z szumami usznymi, jest efektem projekcji wysyłanych do jądra półleżącego przez jądra szwu, które kontrolują poziom serotoniny w mózgu i cykl snu i czuwania.

Istotnych informacji umożliwiających empiryczną weryfikację tej teorii mogą dostarczyć badania stanu spoczynkowego (ang. resting state) mózgu osób doznających wrażeń 
Tabela 1. Charakterystyka pacjentów z szumami usznymi

Table 1. Characterisitics of tinnitus patients

\begin{tabular}{|c|c|c|c|c|c|c|c|}
\hline $\begin{array}{l}\text { Uczestnik } \\
\text { badania }\end{array}$ & Płeć & $\begin{array}{l}\text { Wiek } \\
\text { (lata) }\end{array}$ & $\begin{array}{l}\text { Dźwięk } \\
\text { szumu }\end{array}$ & $\begin{array}{l}\text { Czas trwania } \\
\text { szumu (lata) }\end{array}$ & $\begin{array}{l}\text { Uciążliwość } \\
\text { szumu usznego } \\
\text { (Skala 1-10) }\end{array}$ & $\begin{array}{l}\text { Prawdopodobny } \\
\text { początek szumu }\end{array}$ & BDI \\
\hline Pacjent \# 1 & K & 33 & Szum & 2,5 & 4 & Uraz akustyczny & 7 \\
\hline Pacjent \# 2 & K & 40 & $\begin{array}{l}\text { Gwizdanie, } \\
\text { dzwonienie }\end{array}$ & 1 & 3 & Nieznana & 8 \\
\hline Pacjent \# 3 & K & 43 & Pulsowanie, tomotanie & 4 & 5 & Uraz akustyczny & 10 \\
\hline Pacjent \# 4 & K & 25 & Gwizdanie & 3 & 2 & Stres & 14 \\
\hline Pacjent \# 5 & M & 26 & Dzwonienie & 1,5 & 3 & Uraz akustyczny & 6 \\
\hline Pacjent \# 6 & M & 30 & Świst & 6 & 2 & Przemęczenie & 11 \\
\hline
\end{tabular}

BDI (Beck Depression Inventory) - Kwestionariusz Depresji Becka.

szumów usznych. Badania na zwierzętach, u których wywołano szumy uszne za pomocą lezji chemicznych, wykazały zaburzenia spoczynkowej aktywności komórek nerwowych ośrodkowego układu słuchowego [23-25]. U ludzi spoczynkową aktywność mózgu rejestruje się z zastosowaniem technik neuroobrazowania. Przykładowo, metodą fMRI można zbadać połączenia funkcjonalne (ang. functional connectivity) między różnymi strukturami mózgu, które współdziałają ze sobą, podczas gdy osoba badana leży wewnątrz skanera rezonansu i nie wykonuje żadnego zadania. Testy prowadzone na sieciach mózgowych w stanie spoczynku pozwalają wyrysować swoiste mapy wewnętrznych połączeń między różnymi obszarami mózgu. Aktywność stanu spoczynkowego scharakteryzowano jako „tryb domyślny mózgu" (ang. default mode), który podczas wykonywania zadań wyłączał się, aby pojawić się znowu wtedy, gdy mózg nie pracował już tak intensywnie [26].

U pacjentów z przewlekłymi szumami usznymi w porównaniu z osobami bez tinnitusa wykazano wzmożoną współzależność aktywności struktur mózgu takich jak: pień mózgu, móżdżek, jądra podstawy, jądro półleżące, obszary otaczające hipokamp, prawe okolice czołowe i ciemieniowe, lewy obszar sensomotoryczny oraz lewy górny zakręt skroniowy. Zaobserwowano również zmniejszenie współdziałania ze sobą prawej pierwotnej kory słuchowej, lewego zakrętu wrzecionowatego, lewej okolicy czołowej i kory potylicznej [27]. Wynik ten wskazuje na rolę wzajemnych oddziaływań korowo-podkorowych w percepcji szumów usznych.

Badano również aktywność spoczynkową mózgu pacjentów z uciążliwymi szumami usznymi. Stwierdzono ujemne korelacje między aktywnością kory słuchowej i wzrokowej (potylicznej), co może oznaczać albo zmniejszanie się odpowiedzi hemodynamicznej mózgu, mierzonej metodą fMRI w korze słuchowej wraz ze wzrostem aktywności kory wzrokowej, albo sytuację odwrotną [28]. Z kolei u pacjentów, u których szum uszny nie powodował wyraźnego dyskomfortu, nie stwierdzono specyficznych zmian w aktywności spoczynkowej mózgu [29].

Aktywność spoczynkową mózgu pacjentów z szumami usznymi można również badać za pomocą metod elektrofizjologicznych. W tym przypadku analiza EEG polega na obliczaniu mocy widma sygnału rejestrowanego w poszczególnych regionach mózgu dla różnych pasm częstotliwości: delta, theta, alfa, beta oraz lokalizacji źródła tych pasm mózgu. Istniejące wyniki wskazują na rolę wzajemnych powiązań obszarów kory słuchowej, czołowej i niektórych struktur należących do układu limbicznego (zakręt obręczy) w procesie powstawania wrażenia szumów usznych [30,31].

W niniejszej pracy przedstawiono wstępne wyniki elektrofizjologicznej aktywności spoczynkowej mózgu osób z przewlekłymi szumami usznymi. Badania przeprowadzono z udziałem pacjentów Światowego Centrum Słuchu Instytutu Fizjologii i Patologii Słuchu w Kajetanach.

\section{Materiał i metoda}

W badaniu uczestniczyło 13 osób (9 kobiet, 4 mężczyzn) z prawidłowym słuchem, wśród których było 6 pacjentów Instytutu Fizjologii i Patologii Słuchu (4 kobiety, 2 mężczyzn, średni wiek $=32$ lata i 10 miesięcy \pm 7 lat i 5 miesięcy) z przewlekłymi (trwającymi minimum 6 miesięcy) obustronnymi szumami usznymi oraz 7 osób bez szumów usznych (5 kobiet, 2 mężczyzn, średni wiek $=30$ lat \pm 5 miesięcy). Żadna z osób uczestniczących w badaniach nie cierpiała na zaburzenia neuropsychiatryczne, nadwrażliwość słuchową oraz nie przyjmowała leków mogących wpływać na ośrodkowy układ nerwowy. Dokładne dane dotyczące grupy pacjentów przedstawiono w tabeli 1 .

Każda osoba badana podpisała świadomą zgodę na uczestnictwo w badaniach. Zastosowane procedury uzyskały zgodę Komisji Bioetycznej przy Instytucie Fizjologii i Patologii Słuchu.

Pacjenci oprócz Kwestionariusza Charakterystyki Szumu Usznego, specjalnie opracowanego dla potrzeb projektu, wypełniali Kwestionariusz Depresji Becka (BDI Beck Depression Inventory) [32], przesiewowe narzędzie do oceny obecności i nasilenia objawów obniżonego nastroju. BDI zawiera 21 stwierdzeń dotyczących samopoczucia w ciągu ostatniej doby (za ustosunkowanie się do każdego z nich można uzyskać od 0 do 3 punktów). Wynik w zakresie od 0 do 9 punktów wskazuje na brak depresji lub jej łagodną postać. 

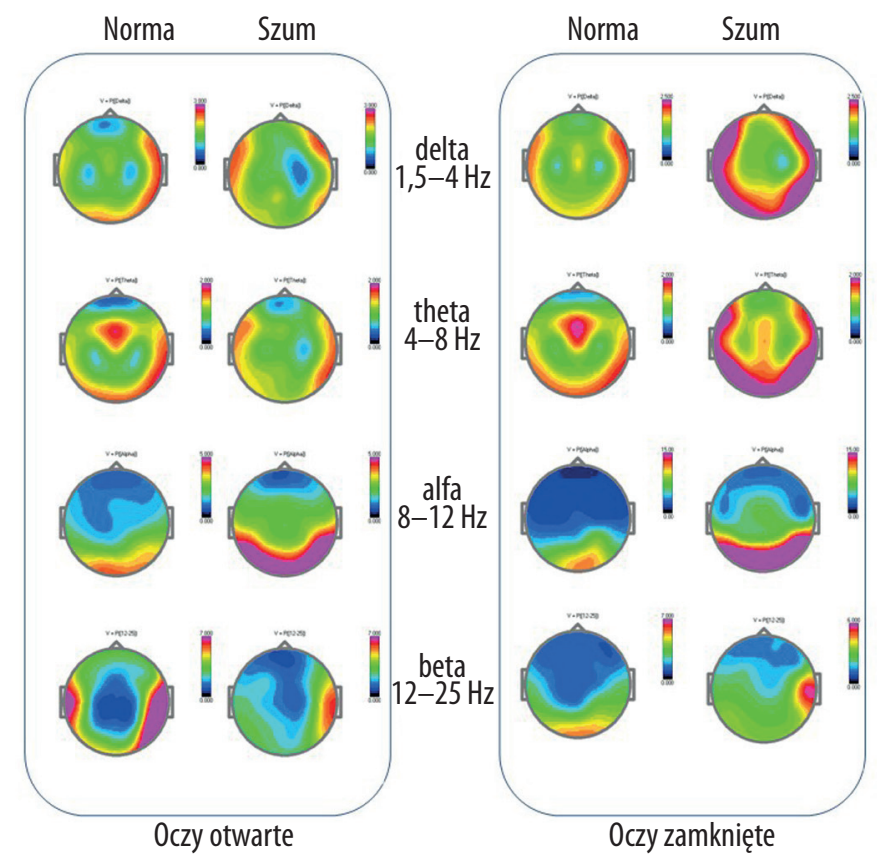

Rycina 1. Mapy rozkładu mocy bezwzględnej w różnych pasmach częstotliwości obliczone z sygnałów EEG zarejestrowanych w dwóch stanach spoczynkowych (oczy otwarte i oczy zamknięte) u osób zdrowych i pacjentów z szumami usznymi

Figure 1. The maps of absolute spectra power distribution for different frequency bands calculated from EEG signals registered in two resting states ("eyes open" and "eyes closed") in tinnitus patients and in control group
U wszystkich osób badanych rejestrowano spoczynkową aktywność bioelektryczną mózgu. Zadanie polegało na siedzeniu w wygodnym fotelu i relaksowaniu się przez 3 minuty z oczami otwartymi i przez 3 minuty - z oczami zamkniętymi. Kolejność bloków „oczy otwarte” i „oczy zamknięte" była losowa.

Sygnał EEG rejestrowano za pomocą 21-kanałowego aparatu firmy Mitsar. Dziewiętnaście chlorosrebrowych elektrod rozmieszczono zgodnie $\mathrm{z}$ międzynarodowym systemem 10-20 [33]. Elektroda uziemiająca była umieszczona na czole. Oporność wszystkich elektrod wynosiła mniej niż $5 \mathrm{k} \Omega$. Sygnał EEG rejestrowano względem sprzężonych płatków uszu i był filtrowany w paśmie od 0,5 do $50 \mathrm{~Hz}$. Częstotliwość próbkowania wynosiła $250 \mathrm{~Hz}$.

Sygnał EEG poddano analizie ilościowej (ang. quantitative EEG, QEEG), używając oprogramowania Win EEG (Mitsar). Artefakty z ruchów gałek ocznych były usuwane $\mathrm{z}$ zastosowaniem metody Independent Component Analysis (ICA) poprzez eliminację składowych korespondujących $z$ mruganiem oczu $[34,35]$. Segmenty sygnału EEG $\mathrm{z}$ amplitudą $>100 \mu \mathrm{V}$ i/lub $\mathrm{z}$ amplitudą $>35 \mu \mathrm{V}$ w paśmie $20-35 \mathrm{~Hz}$ oraz $>50 \mu \mathrm{V}$ w paśmie $0-1 \mathrm{~Hz}$ zostały automatycznie oznaczone i wyłączone z dalszej analizy. Ponadto sygnał poddany został inspekcji wzrokowej w celu sprawdzenia, czy wszystkie artefakty zostały prawidłowo usunięte.

$\mathrm{Na}$ dalszych etapach analizy sygnał EEG podzielono na 4,096-sekundowe segmenty i poddano analizie widmowej metodą transformaty Fouriera (ang. Fast Fourier Transform, FFT). Obliczono bezwzględne widma mocy oddzielnie dla każdego bloku („oczy otwarte” i „oczy zamknięte”) u każdej osoby badanej. Widma mocy powstałe $z$ uśrednień sygnału z mniej niż 30 segmentów nie zostały włączone do dalszych analiz. Przedmiotem analizy były widma mocy bezwzględnej następujących zakresów częstotliwości: delta $(1,5-4 \mathrm{~Hz})$, theta $(4-8 \mathrm{~Hz})$, alfa $(8-12 \mathrm{~Hz})$ i beta (12-25 Hz).

Ze względu na niewielką liczebność porównywanych grup nie przeprowadzono analiz statystycznych uzyskanych wyników.

\section{Wyniki}

Pacjenci charakteryzowali dźwięk swoich szumów usznych jako „dzwonienie”, „szum” lub „pulsowanie” o zmiennym natężeniu w ciągu dnia. Ponadto oceniali szumy uszne jako umiarkowanie uporczywe, nieprzeszkadzające w codziennym życiu (włączając aktywność zawodową). Wyniki uzyskane w BDI wskazywały na brak depresji lub łagodne jej nasilenie (tabela 1).

\section{Badanie QEEG}

Zaobserwowano odmienny wzorzec bioelektrycznej aktywności spoczynkowej mózgu u pacjentów z szumami usznymi w porównaniu z grupą kontrolną (ryciny 1 i 2). Analiza ilościowa wykazała większą ekspresję fal wolnych theta i delta $(1,5-8 \mathrm{~Hz})$ w okolicach czołowo-skroniowych, skroniowych i potylicznych przy oczach zamkniętych u pacjentów z szumami usznymi (średnia moc bezwzględna sygnału zarejestrowanego na elektrodach F7, T3, T5, O1 i F8, T4, T6, O2 wynosiła 2,25 $\mu \mathrm{V}^{2}$ ) niż w grupie kontrolnej (średnia moc sygnału na tych elektrodach: $1,35 \mu \mathrm{V}^{2}$ ). Ponadto obserwowano obniżoną ekspresję aktywności theta w części centralnej pasa czołowego u pacjentów z szumami usznymi (średnia moc sygnału na elektrodzie Fz: $1,5 \mu \mathrm{V}^{2}$ ) w porównaniu $\mathrm{z}$ osobami zdrowymi (średnia moc sygnału na elektrodzie Fz: $2 \mu \mathrm{V}^{2}$ ). Efekt ten był widoczny $\mathrm{w}$ stanie relaksacji z oczami zamkniętymi. Ponadto u pacjentów z szumami usznymi, zarówno przy oczach otwartych jak i zamkniętych, wykazano zwiększoną ilość fal alfa 

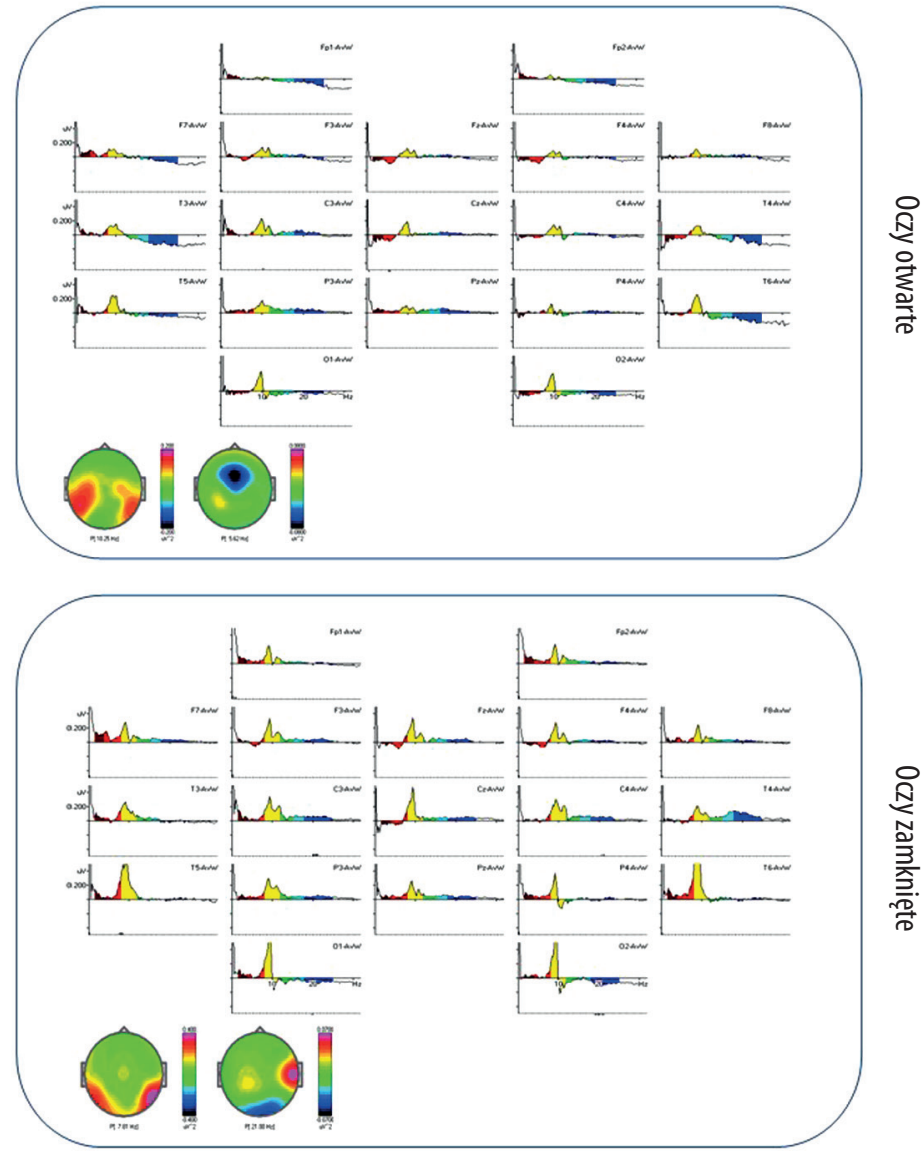

Rycina 2. Widma różnicowe bezwzględnej mocy sygnałów obliczone oddzielnie dla każdej z elektrod. Poszczególne widma obliczono odejmując od średnich widm mocy sygnałów EEG pacjentów z szumami usznymi średnie widma mocy obliczone z sygnałów EEG osób zdrowych. Poniżej przedstawiono mapy rozkładu pojedynczych częstotliwości, które najbardziej różnity obie badane grupy

Figure 2. Differential absolute spectra power of EEG signals calculated separately for each electrode. Particular power spectra were computed by subtracting the avereged spectra power of control group from the averaged power of tinnitus patients. The maps of distribution of frequencies that most differentiate the compared groups are presented below w okolicach skroniowo-potylicznych i potylicznych. Dla oczu otwartych średnia moc sygnału na elektrodach T5, T6, O1 i O2 u pacjentów wynosiła $5 \mu \mathrm{V}^{2}$, a w grupie kontrolnej: $3,2 \mu \mathrm{V}^{2}$. Dla oczu zamkniętych różnica w ekspresji fal alfa była bardziej wyraźna: $15 \mu \mathrm{V}^{2}$ i 7,3 $\mu \mathrm{V}^{2}$ odpowiednio u pacjentów z szumami usznymi i osób z grupy kontrolnej.

Oprócz różnic w zakresie czynności wolnej u pacjentów $\mathrm{z}$ szumami usznymi obserwowano również różnice $\mathrm{w}$ zakresie szybkiej aktywności beta $(12-25 \mathrm{~Hz})$. W stanie oczu zamkniętych pacjenci z szumami usznymi mieli wyższą bezwzględną moc sygnału w prawej skroni w porównaniu $z$ grupą kontrolną (odpowiednio $6 \mu \mathrm{V}^{2}$ i 3,5 $\mu \mathrm{V}^{2}$ na elektrodzie T6). Z kolei w stanie oczu otwartych czynność beta u pacjentów była zaniżona w obu okolicach skroniowych zwłaszcza po lewej stronie (uśredniona moc sygnału na elektrodach lewopółkulowych T3 i T5 wynosiła $2,75 \mu \mathrm{V}^{2}$, a $\mathrm{w}$ grupie kontrolnej $-6,5 \mu \mathrm{V}^{2}$ ).

\section{Dyskusja}

W pracy przedstawiono wyniki pilotażowych badań bioelektrycznej aktywności spoczynkowej mózgu u pacjentów z szumami usznymi. W grupie tej wykazano nadmierną ekspresję zarówno fal nisko- jak i wysokoczęstotliwościowych. Podobne wyniki uzyskali również inni autorzy. Przykładowo, w badaniach Moazami-Goudarzi i wsp. [30] zastosowano większą liczbę elektrod $(n=60)$ niż w eksperymencie opisanym w tej pracy, co pozwoliło autorom zidentyfikować źródła wyróżnionych pasm aktywności mózgu. Generatory fal delta, theta, alfa i beta były zlokalizowane w lewej okolicy skroniowo-ciemieniowej, przednim zakręcie obręczy i okolicach hipokampa. W naszych badaniach różnice w zakresie fal wolnych były widoczne zarówno w przednich, jak i tylnych obszarach mózgu, natomiast fal szybkich wyłącznie w okolicy skroniowej. Można zatem stwierdzić, że przedstawione w tej pracy wstępne wyniki badań spoczynkowej aktywności mózgu potwierdzają rezultaty uzyskane przez innych autorów.

W wielu badaniach z zastosowaniem metody QEEG [np. 36,37] wykazano wzmożoną wysokoczęstotliwościową aktywność mózgu w okolicy skroniowej u pacjentów z szumami usznymi (tzw. hot spots). Na uwagę zasługuje kwestia lateralizacji tej aktywności. W badaniach Ashtona i wsp. [37] u połowy osób badanych z jednostronnymi szumami usznymi nadmierna ekspresja fal szybkich występowała ipsilateralnie do szumu. U pozostałych uczestników tego badania zwiększoną aktywność beta rejestrowano po stronie ucha z szumem. Intersujące, że w badaniach przedstawianych $\mathrm{w}$ naszej pracy nadmierna wysokoczęstotliwościowa czynność mózgu u pacjentów z obustronnymi szumami usznymi była zlokalizowana w prawej okolicy skroniowej. Ponieważ projekcje ze ślimaka docierają głównie do kontralateralnej kory słuchowej, spodziewaliśmy się, że u pacjentów z obustronnymi szumami usznymi nie będziemy obserwować efektu lateralizacji. Lokalizacja wysokoczęstotliwościowej czynności mózgu może jednak zależeć od pochodzenia szumów usznych. W przypadku 
pozaślimakowego pochodzenia szumów usznych jest bardziej prawdopodobne, że związana z nimi aktywność mózgu będzie obserwowana przeciwstronnie do tinnitusa. Natomiast jeśli generator szumów znajduje się w korze skroniowej, szum może być słyszany po tej samej stronie. Wiadomo również, że wrażenie szumu usznego pozostaje pomimo przecięcia nerwu słuchowego [38]. W przypadku uczestników badania opisywanego w tej pracy mieliśmy do czynienia $\mathrm{z}$ różnorodną prawdopodobną przyczyną szumów usznych, których natężenie i dźwięk często zmieniały się w ciągu dnia. Może to po części wyjaśniać obserwowany efekt asymetrii fali beta.

Badania z zastosowaniem magnetoencefalografii (MEG) wskazują, że tinnitus jest spowodowany przez nadmierną spontaniczną ekspresję wysokoczęstotliwościowej czynności mózgu (gamma >30 Hz), która jest konsekwencją hiperpolaryzacji jąder wzgórza i ciała kolankowatego przyśrodkowego [39]. W naszych badaniach, głównie ze względu na ograniczenia techniczne, analizowaliśmy aktywność mózgu o częstotliwości do $25 \mathrm{~Hz}$, jednakże nadmierna ekspresja szybkich fal w okolicy skroniowej przy oczach zamkniętych wskazuje na rolę wysokoczęstotliwościowej czynności mózgu w procesie generacji szumów usznych.

W naszych badaniach obserwowaliśmy również obniżoną ekspresję fal theta w okolicy czołowo-centralnej u osób z szumami usznymi. Przedni zakręt obręczy jest jednym z możliwych źródeł czynności theta [40]. Jednocześnie fale theta są odpowiedzialne za procesy uwagowe [41], również za zwracanie uwagi na słyszane szumy. Obniżona aktywność theta $\mathrm{w}$ tym regionie u pacjentów $\mathrm{z}$ tinnitusem może wskazywać, że osoby te przyzwyczaiły się do ich brzmienia i nauczyły się ich nie dostrzegać w codziennym życiu. Istotnie, uczestnicy naszego badania raportowali, że słyszane przez nich szumy uszne nie są dla nich zbyt uciążliwe i nie powodują wyraźnego dyskomfortu.
Z obniżoną aktywnością fal theta w okolicy czołowo-centralnej u osób z szumami usznymi współwystępowała wzmożona ekspresja tej czynności w okolicach czołowo-skroniowych. Istnieją dane pokazujące, że synchroniczne oscylacje theta pochodzą z bocznych okolic czołowych [42] i są związane ze świadomą percepcję bodźców. U osób z szumami usznymi nadmierna aktywność theta $\mathrm{w}$ tym regionie może być zatem odpowiedzialna za fantomową percepcję dźwięków.

Na koniec warto zauważyć, że w pracy przedstawiono jedynie wstępne wyniki badań. Wydają się one jednak na tyle obiecujące, że warto je kontynuować $\mathrm{z}$ udziałem większej liczby osób badanych. Planowane jest zbadanie aktywności spoczynkowej mózgu pacjentów z szumami usznymi, którzy mają zaburzenia słuchu i/lub inne objawy często współwystępujące z percepcją tinnitusa, takie jak nadwrażliwość słuchowa, depresja czy bezsenność. Porównanie aktywności spoczynkowej mózgu w różnych grupach pacjentów poszerzy istniejącą wiedzę na temat mózgowych mechanizmów warunkujących percepcję szumów usznych, a tym samym może przyczynić się do opracowywania nowych metod terapii i dostosowywania ich do indywidualnych potrzeb pacjentów.

\section{Wnioski}

Uzyskane wyniki wskazują na rolę obszarów czołowych i skroniowych kory mózgu w procesie generowania szumów usznych. Identyfikacja obszarów mózgu o zwiększonej aktywności może być stosowana do poszerzenia diagnostyki oraz planowania i monitorowania postępów w terapii szumów usznych.

\section{Podziękowania}

Badania finansowane $\mathrm{z}$ grantu Narodowego Centrum Nauki nr 2011/03/D/NZ4/02431.

\section{Piśmiennictwo:}

1. Skarżyński H. Szumy uszne i nadwrażliwość na dźwięki. Warszawa: Instytut Fizjologii i Patologii Słuchu; 1998.

2. Bartnik G. Szumy uszne i nadwrażliwość słuchowa. Warszawa: Instytut Fizjologii i Patologii Słuchu; 2010.

3. Fabijańska A. Badania epidemiologiczne szumów usznych i nadwrażliwości słuchowej na świecie i w Polsce. W: Skarżyński H, red. Warszawa: Instytut Fizjologii i Patologii Słuchu; 1998, s. 35-41.

4. Jastreboff PJ. Phantom auditory perception (tinnitus). Mechanisms of generation and perception. Neurosci Res, 1990; 8: 221-54

5. Eggermont JJ, Roberts LE. The neuroscience of tinnitus. Trends Neurosci, 2004; 27(11): 676-82.

6. Rauschecker JP, Leaver AM, Mühlau M. Tuning out the noise: limbic-auditory interactions in tinnitus. Neuron, 2010; 66(6): $819-26$.

7. Melcher JR, Sigalovsky IS, Guinan JJ Jr, Levine RA. Lateralized tinnitus studied with functional magnetic resonance imaging: abnormal inferior colliculus activation. J Neurophysiol, 2000; 83: 1058-72.

8. Melcher JR, Levine RA, Bergevin C, Norris B. The auditory midbrain of people with tinnitus: abnormal sound-evoked activity revisited. Hear Res, 2009; 257(1-2): 63-74.
9. Lanting CP, De Kleine E, Bartels H, Van Dijk P. Functional imaging of unilateral tinnitus using fMRI. Acta Otolaryngol, 2008; 128(4): 415-21.

10. Landgrebe M, Langguth B, Rosengarth K, Braun S, Koch A, Kleinjung $\mathrm{T}$ i wsp. Structural brain changes in tinnitus: grey matter decrease in auditory and non-auditory brain areas. Neuroimage, 2009; 46(1): 213-18.

11. Smits M, Kovacs S, de Ridder D, Peeters RR, van Hecke P, Sunaert S. Lateralization of functional magnetic resonance imaging (fMRI) activation in the auditory pathway of patients with lateralized tinnitus. Neuroradiology, 2007; 49(8): 669-79.

12. Schneider P, Andermann M, Wengenroth M, Goebel R, Flor H. Reduced volume of Heschl's gyrus in tinnitus. NeuroImage, 2009; 45: 927-39.

13. Mühlnickel W, Elbert T, Taub E, Flor H. Reorganization of auditory cortex in tinnitus. Proc Natl Acad Sci USA, 1998; 95: 10340-43.

14. Weisz N, Moratti S, Meinzer M, Dohrmann K, Elbert T. Tinnitus perception and distress is related to abnormal spontaneous brain activity as measured by magnetoencephalography. PLoS Med, 2005; 2(6): e153. 
15. Wienbruch C, Paul I, Weisz N, Elbert T, Roberts LE. Frequency organization of the $40-\mathrm{Hz}$ auditory steady-state response in normal hearing and in tinnitus. Neuroimage, 2006; 33: 180-94.

16. Lanting CP, De Kleine E, Van Dijk P. Neural activity underlying tinnitus generation: Results from PET and fMRI. Hear Res, 2009; 255: 1-13.

17. Hallam RS. Correlates of sleep disturbance in chronic distressing tinnitus. Scand Audiol, 1996; 25(4): 263-66.

18. Mirz F, Gjedde A, Sodkilde-Jrgensen H, Pedersen CB. Functional brain imaging of tinnitus-like perception induced by aversive auditory stimuli. Neuroreport, 2000; 11(3): 633-37.

19. Plewnia C, Reimold M, Najib A, Brehm B, Reischl G, Plontke SK i wsp. Dose-dependent attenuation of auditory phantom perception (tinnitus) by pet-guided repetitive transcranial magnetic stimulation. Hum Brain Mapp, 2007; 28(3): 238-46.

20. Lockwood AH, Salvi RJ, Coad ML, Towsley ML, Wack DS, Murphy BW. The functional neuroanatomy of tinnitus: evidence for limbic system links and neural plasticity. Neurology, 1998; 50 (1): 114-20.

21. Mühlau M, Rauschecker JP, Oestreicher E, Gaser C, Rottinger $\mathrm{M}$, Wohlschlager AM i wsp. Structural brain changes in tinnitus. Cereb Cortex, 2006; 16: 1283-88.

22. Leaver AM, Renier L, Chevillet MA, Morgan S, Kim HJ, Rauschecker JP. Dysregulation of limbic and auditory networks in tinnitus. Neuron, 2011; 69(1): 33-43.

23. Eggermont JJ, Kenmochi M. Salicylate and quinine selectively increase spontaneous firing rates in secondary auditory cortex. Hear Res, 1998; 117: 149-60.

24. Seki S, Eggermont JJ. Changes in spontaneous firing rate and neural synchrony in cat primary auditory cortex after localized tone-induced hearing loss. Hear Res, 2003; 180: 28-38.

25. Norena AJ, Eggermont JJ. Changes in spontaneous neural activity immediately after an acoustictrauma: implications for neural correlates of tinnitus. Hear Res, 2003; 183: 137-53.

26. Raichle ME, Snyder AZ. A default mode of brain function: a brief history of an evolving idea. Neuroimage, 2007; 37(4): 1083-90.

27. Maudoux A, Lefebvre P, Cabay JE, Demertzi A, Vanhaudenhuyse A, Laureys S i wsp. Auditory resting-state network connectivity in tinnitus: a functional MRI study. PLoS One, 2012; 7(5): e36222.

28. Burton H, Wineland A, Bhattacharya M, Nicklaus J, Garcia KS, Piccirillo JF. ltered networks in bothersome tinnitus: a functional connectivity study. BMC Neurosci, 2012; 13: 3 .
29. Wineland AM, Burton H, Piccirillo J. Functional connectivity networks in nonbothersome tinnitus. Otolaryngol Head Neck Surg, 2012; 147(5): 900-6.

30. Moazami-Goudarzi M, Michels L, Weisz N, Jeanmonod D. Temporo-insular enhancement of EEG low and high frequencies in patients with chronic tinnitus. QEEG study of chronic tinnitus patients. BMC Neurosci, 2010; 11: 40.

31. Vanneste S, De Ridder D. The auditory and non-auditory brain areas involved in tinnitus. An emergent property of multiple parallel overlapping subnetworks. Front Syst Neurosci, 2012; 6: 31.

32. Beck AT, Ward CH, Mendelson M, Mock J, Erbaugh J. An inventory for measuring depression. Arch Gen Psychiatry, 1961; 4(6): 561-71.

33. Jasper HH. Report of the Committee on Methods of Clinical Examination in Electroencephalography. Electroenceph Clin Neurophysiol, 1958; 10: 370-71.

34. Vigário RN. Extraction of ocular artefacts from EEG using independent component analysis. Electroencephalogr Clin Neurophysiol, 1997; 103: 395-404.

35. Jung TP, Makeig S, Westerfeld M, Townsend J, Courchesne E, Sejnowski TJ. Removal of eye activity artifacts from visual event-related potentials in normal and clinical subjects. Clin Neurophysiol, 2000; 111: 1745-58.

36. Shulman A, Goldstein B. Quantitative electroencephalography: preliminary report-tinnitus. Int Tinnitus J, 2002; 8(2): 77-86.

37. Ashton H, Reid K, Marsh R, Johnson I, Alter K, Griffiths T. High frequency localised „hot spots” in temporal lobes of patients with intractable tinnitus: a quantitative electroencephalographic (QEEG) study. Neurosci Lett, 2007; 426(1): 23-28.

38. Eggermont JJ, Roberts LE. The neuroscience of tinnitus, Trends Neurosci, 2004; 27: 676-82.

39. Llinás RR, Ribary U, Jeanmonod D, Kronberg E, Mitra PP. Thalamocortical dysrhythmia: a neurological and neuropsychiatric syndrome characterized by magnetoencephalography. Proc Natl Acad Sci USA, 1999; 96: 15222-27.

40. Asada H, Fukuda Y, Tsunoda S, Yamaguchi M, Tonoike M. Frontal midline theta rhythms reflect alternative activation of prefrontal cortex and anterior cingulate cortex in humans. Neurosci Lett, 1999; 274: 29-32.

41. Inanaga $\mathrm{K}$. Frontal midline theta rhythm and mental activity. Psychiatry Clin Neurosci, 1998; 52: 555-66.

42. Melloni L, Molina C, Pena M, Torres D, Singer W, Rodriguez E. Synchronization of neural activity across cortical areas correlates with conscious perception. J Neurosci, 2007; 27(11): 2858-65. 